University of Nebraska - Lincoln

DigitalCommons@University of Nebraska - Lincoln

Faculty Publications from the Harold W. Manter Laboratory of Parasitology

8-1974

\title{
On Some Anoplocephaline Cestodes from Pikas, Ochotona spp. (Lagomorpha), in Nepal, with the Description of Ectopocephalium abei gen. et sp. $\mathbf{n}$.
}

Robert L. Rausch

University of Washington, rausch@uw.edu

Masashi Ohbayashi

Hokkaido University

Follow this and additional works at: https://digitalcommons.unl.edu/parasitologyfacpubs

Part of the Parasitology Commons

Rausch, Robert L. and Ohbayashi, Masashi, "On Some Anoplocephaline Cestodes from Pikas, Ochotona spp. (Lagomorpha), in Nepal, with the Description of Ectopocephalium abei gen. et sp. n." (1974). Faculty Publications from the Harold W. Manter Laboratory of Parasitology. 374.

https://digitalcommons.unl.edu/parasitologyfacpubs/374

This Article is brought to you for free and open access by the Parasitology, Harold W. Manter Laboratory of at DigitalCommons@University of Nebraska - Lincoln. It has been accepted for inclusion in Faculty Publications from the Harold W. Manter Laboratory of Parasitology by an authorized administrator of DigitalCommons@University of Nebraska - Lincoln. 


\title{
ON SOME ANOPLOCEPHALINE CESTODES FROM PIKAS, OCHOTONA SPP. (LAGOMORPHA), IN NEPAL, WITH THE DESCRIPTION OF ECTOPOCEPHALIUM ABEI GEN. ET SP. N.*
}

\author{
Robert L. Rausch $\dagger$ and Masashi Ohbayashił
}

ABStract: Three species of anoplocephaline cestodes, Anoplocephalinae gen. et sp. indet., Schizorchis cf. altaica Gvozdev, 1951, and Ectopocephalium abei gen. et sp. n., are reported from pikas, Ochotona roylei (Ogilby) and O. macrotis (Günther), from central Nepal. The taxonomic status of Schizorchis esarsi Lovekar et al., 1972, and of Schizorchodes dipodomi Bienek and Grundmann, 1972, is discussed, with the conclusion that both species belong in the subfamily Linstowiinae, near the genus Atriotaenia Sandground, 1926. Ectopocephalium gen. n. is distinguished from other genera in the subfamily Anoplocephalinae by the modified anterior portion of the strobila, which is embedded in the tissue of the sacculus rotundus (lower ileum) of the host, and by the arrangement of the genital organs. The attachment of $E$. abei and the consequent tissue response are described, and the zoogeography of cestodes in pikas is briefly discussed.

During March-July 1968, a biological survey of Nepal was undertaken by an expedition from the University of Hokkaido, with support of the Hokkaido University Himalayan Committee. The objectives included an investigation of the small mammals of the region, under the direction of Dr. Hisashi Abe, of Hokkaido University, who kindly made available to us a large series of preserved carcasses for parasitological examination. Information concerning the taxonomy and ecology of these mammals has been published by Abe (1971).

Among the preserved materials was a series of pikas, Ochotona spp., from which we obtained anoplocephaline cestodes representing three species. One of these exhibited a combination of characters that was unlike any within the genera recognized in the subfamily Anoplocephalinae. The results of the study of these cestodes are reported in the present paper.

\section{MATERIALS AND METHODS}

The collection included 9 pikas, identified by Dr. Abe as Ochotona macrotis (Günther), $1 ; 0$. roylei (Ogilby), 7; Ochotona sp. indet., 1. After removal of the viscera from the formalin-preserved carcasses, the organs were opened separately in water. Cestodes in the small intestine were placed

Received for publication 31 January 1974.

* Scientific Results of Hokkaido University Expeditions to the Himalaya. Zoology No. 4.

$\dagger$ Arctic Health Research Center, Center for Disease Control, Public Health Service, Fairbanks, Alaska 99701.

$\$$ Department of Parasitology, Faculty of Veterinary Medicine, Hokkaido University, Sapporo 060, Japan. in $10 \%$ formalin solution. Those in the sacculus rotundus (at the distal end of the ileum) had to be dissected free of fibrous tissue that closely surrounded the anterior portion of the strobila where it passed through the intestinal wall; sacculi from 3 animals, with cestodes in situ, were preserved intact. After staining in Semichon's acetic carmine or in Ehrlich's acid hematoxylin, cestodes to be mounted entire were straightened in $70 \%$ ethanol, hardened by further dehydration, and cleared in terpineol. The cuticle and underlying tissues were removed from the anterior portions of selected strobilae to facilitate study of the genital ducts. Thick transverse sections were cut by means of a razor blade under low magnification. Cestodes occurring in the sacculus rotundus were sectioned serially, individually and in situ, after paraffin-embedding, and were stained in hematoxylin-eosin, Mallory's aniline blue collagen, May-Grünwald Giemsa, Weigert-van Gieson, and by the periodic acid-Schiff method.

\section{RESULTS}

A species of cestode occupying the sacculus rotundus was found in the one big-eared pika, Ochotona macrotis, and in five Royle's pikas, O. roylei. The big-eared pika had another anoplocephaline cestode in the small intestine, and one of the Royle's pikas had in the jejunum two cestodes of the genus Schizorchis Hanson, 1948.

Names of Eurasian mammals are according to Ellerman and Morrison-Scott (1951). All measurements are in microns unless otherwise stated.

Anoplocephalinae gen. et sp. indet.

A single specimen, lacking scolex and part of the strobila, was found in a big-eared pika 
collected at Gosainkund, at an elevation of $4,300 \mathrm{~m}$, on 4 June 1968 .

\section{Description}

Incomplete strobila $31.5 \mathrm{~mm}$ long, with 111 segments; maximum width $3.2 \mathrm{~mm}$, attained in gravid segments. Strobila attenuated anteriorly, with slightly serrate margins. First 64 segments immature or mature. All segments wider than long, with length gradually increasing posteriad. Length/width ratio of mature segments about 1:9. Gravid segments up to $1.08 \mathrm{~mm}$ long, with velum making up about $1 / 3$; length/width ratio about $1: 2$. Excretory system consisting of dorsal and ventral longitudinal canals bilaterally, with ventral canals connected across posterior margin of segment. Genital pores bilateral, situated at middle of margin in mature segments; genital ducts passing dorsally across longitudinal excretory canals. Cirrus sac elongate, 217 to 294 long by 108 to 155 in maximum diameter near distal end; not extending mediad to longitudinal excretory canals. Vas deferens much convoluted, forming external seminal vesicle. Subspherical testes, about 60 per segment, occupying field between female genital organs and extending through most of length of mature segments. Female genital organs double; lobed ovaries situated bilaterally near middle of mature segments, just medial to longitudinal excretory canals. Lobed vitelline gland ventral to ovary, situated posteriorly and somewhat medially. Vagina opening ventral and slightly posterior to cirrus sac, extending mediad as thin-walled, convoluted tube and forming large seminal receptacle ventral to ovary. Early uterus appearing as transverse tube situated anteriorly in mature segment, with ends passing dorsally across longitudinal excretory canals. Developing uterus with anterior and posterior sacculations, displacing cirrus sac and vagina anteriad, and finally filling entire gravid segment. Eggs 52 to 56 by 40 to 48 . Pyriform apparatus present.

\section{Remarks}

In generic characters, this cestode most closely resembles Mosgovoyia Spasskii, 1951, from which it seems to differ only in having the testes between the female genital organs, rather than posterior to them.

\section{Schizorchis cf. altaica Gvozdev, 1951}

(Fig. 1)

Two complete, fully developed strobilae were obtained from a Royle's pika collected at Gosainkund on 3 June 1968.

\section{Description}

Strobilae 40 and $41 \mathrm{~mm}$ long, with 199 and 201 segments, respectively. Maximum width $3.5 \mathrm{~mm}$, attained in pregravid segments. Scolex weakly de- veloped, 200 and 260 wide. Strobila, serrated marginally, moderately attenuated anteriorly. All segments wider than long, with relative length increasing posteriad. Length/width ratio of mature segments about 1:14; of fully gravid segments, about 1:4. Genital pores irregularly alternating, slightly anterior to middle of segmental margin in mature segments. Excretory system consisting of dorsal and ventral longitudinal ducts bilaterally, with ventral ducts connected across posterior margin of segment. Ovary near midline, usually slightly porad. Vitelline gland ventral to ovary, near posterior margin of segment. Testes 45 to 70 per segment, forming disjunct, lateral groups extending from lateral margins of ovary porad to longitudinal excretory canals bilaterally. Early uterus appearing as transverse tube, extending to longitudinal excretory canals bilaterally, forming anterior and posterior sacculations in postmature segments, and entirely filling gravid segments. Eggs 57 to 84 by 48 to 63 (avg 20: 74 by 57 ). Pyriform apparatus present.

A slide containing an entire specimen has been deposited in the USNM Helm. Coll., No. 72900.

\section{Remarks}

Two species of Schizorchis are known from Palearctic pikas: S. altaica Gvozdev, 1951, described from the Altai pika, O. alpina (Pallas), from the Katon-Karagaisk region of the southern Altai, and S. yamashitai Rausch, 1963, from the northern pika, O. hyperborea (Pallas), in Hokkaido. Cestodes identified as S. altaica have been reported from pikas representing six species from various regions of middle and eastern Asia (Gvozdev, 1962). In North America, S. ochotonae Hanson, 1948, and S. caballeroi Rausch, 1960, have been described from the Rocky Mountain pika, O. princeps (Richardson), and the collared pika, O. collaris (Nelson), respectively.

S. altaica as originally described by Gvozdev (1951) is much larger than the cestodes from $O$. roylei, having a strobila $150 \mathrm{~mm}$ long by as much as $4 \mathrm{~mm}$ in maximum width, but its size was given as approximately $60 \mathrm{~mm}$ long by 2.3 to $3 \mathrm{~mm}$ by Gvozdev et al. (1970), in their synopsis of the helminths of lagomorphs. These latter dimensions correspond to those given by Spasskii and Ryzhikov (1951) (60 to $70 \mathrm{~mm}$ long; 2.5 to $3 \mathrm{~mm}$ in maximum width) for cestodes identified as S. altaica from Altai pikas collected near Lake Baikal. Although the descriptions of S. altaica are discrepant in some details, a direct comparison of our cestodes with a specimen of S. altaica from a red pika, O. rutila (Severtsov), from Kazakhstan, 
revealed no taxonomic characters by which they could be distinguished. However, the cestodes from $O$. roylei are designated Schizorchis cf. altaica pending study of additional material.

Besides the four species of Schizorchis from pikas, another, S. esarsi Lovekar et al., 1972, has been described from the house mouse, Mus musculus Linnaeus, in India. Since the relationship existing between cestodes of the genus Schizorchis and lagomorphs of the genus Ochotona would seem to be fundamentally the result of parallel phylogeny, the occurrence of a cestode of this genus in a murid would be of unusual interest.

According to the information published by Lovekar et al., this cestode was placed in the genus Schizorchis mainly on the basis of the dispersal of the testes in two lateral groups. However, the testes are not arranged transversely, as in Schizorchis, but are distributed longitudinally in the lateral fields. The uterus was described as being transverse, but the figure of the mature segment (Lovekar et al., fig. 2) shows that it arises as a longitudinal stem that extends anteriad beyond the ovary, apparently with later formation of lateral branches. The relationships of the cirrus sac and the distal portion of the vagina were not shown in detail, although it was stated that a genital atrium was lacking. The presence of a pyriform apparatus was reported, but it was not shown (Lovekar et al., fig. 4). The strobila of this cestode differs markedly from that of any previously known species of Schizorchis in the much greater length/width ratio of the mature segments. The descriptions and figures indicate that this cestode belongs in the subfamily Linstowiinae, rather than in Anoplocephalinae; among Linstowiine genera, it is near Atriotaenia Sandground, 1926.

The respective descriptions and published figures indicate that $\mathrm{S}$. esarsi is remarkably similar morphologically to Schizorchodes dipodomi Bienek and Grundmann, 1973, described from a heteromyid rodent, Dipodomys merriami Mearns, in Utah. The genus Schizorchodes Bienek and Grundmann, 1973, was placed in the family Anoplocephalidae without assignment to subfamily, but it was considered to have its closest affinities with Schizorchis because of the arrangement of the testes in two lateral groups. Although the uterus of Schizorchodes dipodomi was described in the generic diagnosis as being transverse, the figure of the mature segment (Bienek and Grundmann, 1973, fig. 2) shows it arising as a longitudinal stem that extends anteriad on the midline. The subsequent development of the uterus was not described. As shown also in Figure 2, a genital atrium was present, into which the vagina opened posterior to the cirrus sac, rather than ventral to it as was stated in the generic diagnosis. The egg of $\mathrm{S}$. dipodomi lacks a pyriform apparatus. The combination of characters exhibited by $\mathbf{S}$. dipodomi is consistent with its placement in the subfamily Linstowiinae, where it is near Atriotaenia.

\section{Ectopocephalium gen. n.}

\section{Diagnosis}

Anoplocephalidae Fuhrmann, 1907; Anoplocephalinae Fuhrmann, 1907. Cestodes of small size. Anterior portion of strobila modified, embedded in host tissue. Scolex globular, with suckers and prominent apical glands. Excretory system simple, with dorsal and ventral longitudinal ducts bilaterally. Two sets of female reproductive organs in each segment. Genital pores bilateral and marginal; genital ducts passing dorsal to longitudinal excretory canals. Cirrus sac well developed. Testes numerous, situated dorsal and ventral to female genital organs, and distributed across entire segment between longitudinal excretory canals. Uterus transverse, tubular, forming anterior and posterior sacculations. Egg with pyriform apparatus.

Type host: Ochotona roylei (Ogilby) (Lagomorpha: Ochotonidae).

Type species: Ectopocephalium abei sp. n.

\section{Remarks}

The name Ectopocephalium is derived from the Greek, ek (outside), topos (place), and kefalion (diminutive of kefale, head), forming a neuter noun.

\section{Ectopocephalium abei sp. n. (Figs. 2-6)}

\section{Description}

(Based on 10 entire specimens and sections.) Strobila 14 to $22 \mathrm{~mm}$ long, with 34 to $77 \mathrm{seg}$ ments; maximum width 1.6 to $2.7 \mathrm{~mm}$, attained in mature or pregravid segments. Strobila modified anteriorly, forming slender, cylindrical extension of neck within host tissues; modified portion of strobila and neck 1.43 to $1.86 \mathrm{~mm}$ long and 232 to 310 in diameter, comprising $1 / 6$ to $1 / 5$ of strobilar length. Strobila widens at level of entry 

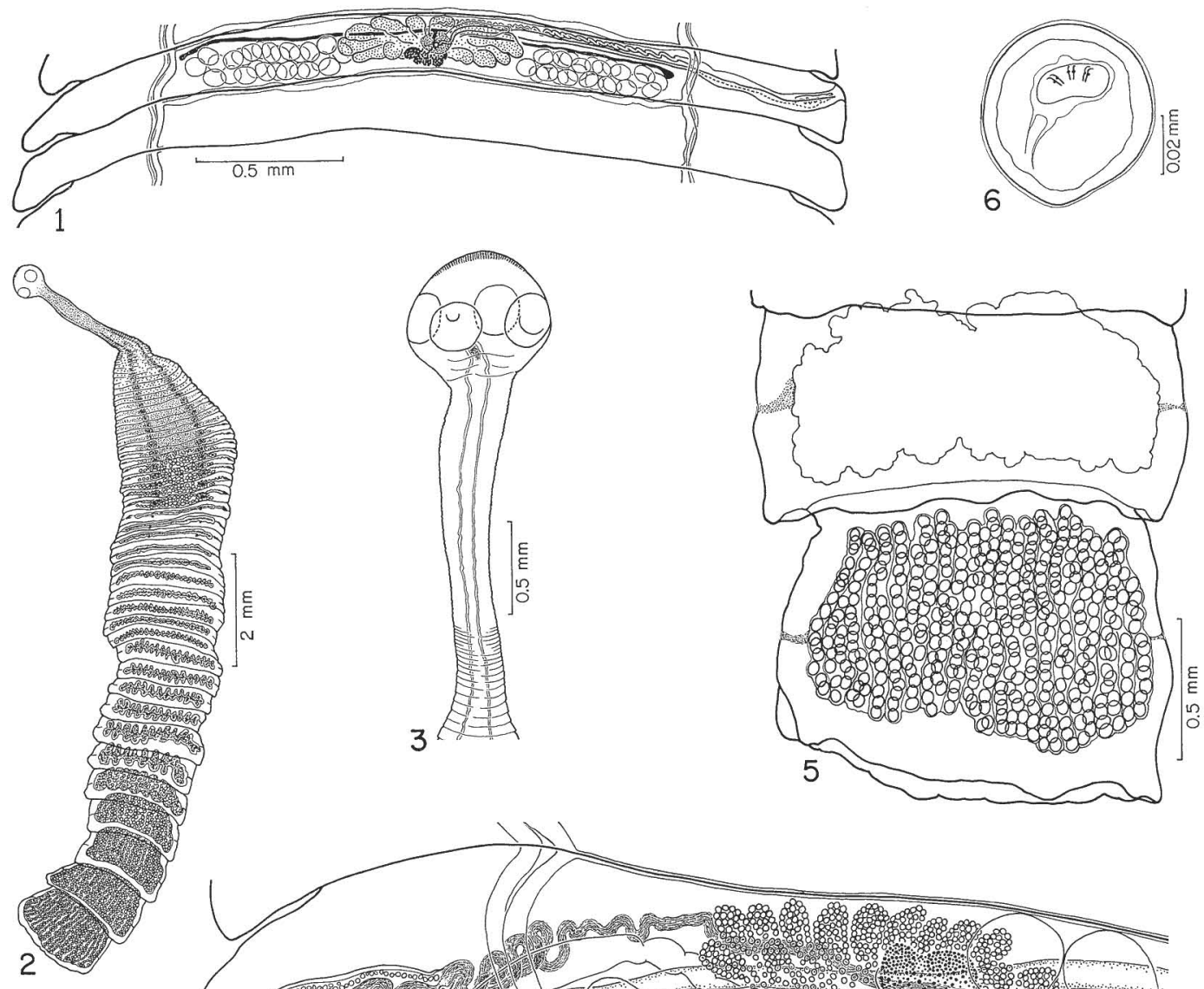

2

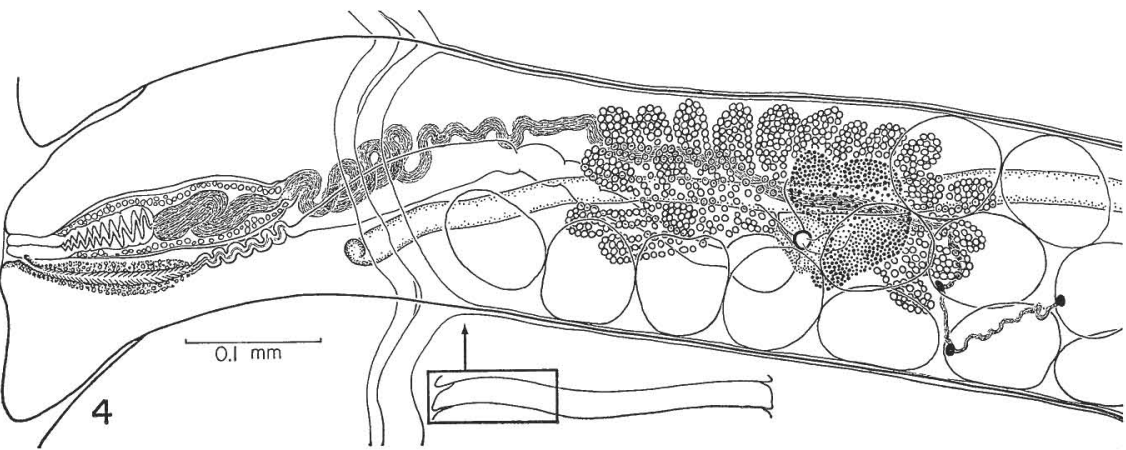

FIGURE 1. Schizorchis cf. altaica, mature segment.

Figures 2-6. Ectopocephalium abei gen. et sp. n. 2. Strobila. 3. Scolex and anterior portion of strobila. 4. Details of genital organs in mature segment. Inset indicates portion of segment enlarged. 5. Gravid segments. 6. Egg.

into intestinal lumen, forming typical segments. Width of segments increasing through about $1 / 2$ of exposed strobila, thereafter decreasing. Approximately $1 / 3$ of strobila consisting of immature and mature segments. Mature segments much wider than long, with length/width ratio about $1: 12$; relative length of segments increasing posteriad, with length/width ratio of $1: 5$ to $1: 2$ in gravid segments. Strobilar margins slightly serrate anteriorly, with serration more strongly defined in late pregravid and gravid segments. Scolex subspherical, relatively large, 418 to 871 in transverse diameter by 465 to 700 long. Four thick-walled, sessile suckers, 232 to 310 in diameter, situated equatorially on scolex. Apex of scolex hemispherical, containing abundant subcuticular glandular cells. Genital pores bilateral, at or just posterior to middle of margin in mature segments. Longitudinal excretory canals closely apposed; ventral canals 12 to 32 in diameter, connected posteriorly across segment by transverse duct about 5 in diameter; dorsal canals 12 to 20 in diameter. Subcuticular layer of longitudinal muscle fibers well developed, approximately 50 in thickness, and comprised of bundles as much as 20 in diameter. Genital ducts ass dorsal to longitudinal excretory 
canals. Cirrus sac thick-walled, 116 to 160 long by 40 to 52 in diameter, directed slightly anteromediad and not extending to longitudinal excretory canals. Internal seminal vesicle present. Vas deferens convoluted, functioning as external seminal vesicle. Testes subspherical, 70 to 80 per segment; 60 to 85 in diameter in mature segments. Testes distributed dorsally across entire segment between longitudinal excretory canals, forming layer 2 or 3 deep in field between female genital organs, and overlapping ovaries ventrally as well as dorsally. Primordia of female genital organs visible proximally in modified anterior portion of strobila. Vagina arising posteriorly near middle of ovary, forming wide, thin-walled seminal receptacle, then taking undulating course laterad, opening at genital pore posteroventral to cirrus sac. Terminal portion (ca. 150 long) of vagina thick-walled, with distal end surrounded by glandular cells. Multilobed ovary situated bilaterally, just medial to longitudinal excretory canals, extending through about $2 / 3$ of length of segment. Corresponding vitelline gland weakly lobed, situated ventrally posteromedial to ovary. Early uterus appearing as simple, transverse tube approximately 25 in diameter, extending across central field of segment, and overlapped by anteriormost testes; laterad from ovaries, ends of uterus deviating somewhat posteriad, passing dorsally across longitudinal excretory canals posterior to genital ducts. Uterus developing anterior and posterior sacculations, eventually enlarging and filling gravid segment. Eggs subspherical, with both greater and lesser diameters from 50 to 65 (avg $51: 59$ by 57 ) (determined from eggs from formalin-preserved gravid segments). Embryos much wider than long, 16 to 25 by 5 to 11 (avg 51: 22 by 8 ); embryonic hooks 7 long. Pyriform apparatus present.

Type host: Ochotona roylei (Ogilby); recorded also from $O$. macrotis (Günther).

Type locality: Gosainkund, Nepal (elev. 4,300 $\mathrm{m})$.

Habitat: Characteristically in sacculus rotundus of host, with scolex and anterior portion of strobila embedded in host tissues.

Type: A permanently mounted strobila has been deposited in the USNM Helm. Coll., No. 72898. Also deposited were cestodes preserved in situ in the sacculus rotundus of $O$. roylei, Thare Pati, Nepal (elev. 3,530 m), No. 72899 .

This cestode has been named in honor of Dr. Hisashi Abe, Institute of Applied Zoology, Hokkaido University.

\section{Remarks}

Adaptation to a process of attachment unique among cestodes of the family Anoplocephalidae has resulted in structural modifications that distinguish Ectopocephalium from other genera in the subfamily Anoplocephalinae. In the structure of the mature segment,
Ectopocephalium resembles Mosgovoyia Spasskii, 1951.

Primarily on the basis of form of uterus, Spasskii (1951, p. 413) revised the genus Cittotaenia Riehm, 1881, removing Cittotaenia s. str. (having a reticulate uterus) to a new subfamily, Monieziinae Spasskii, 1951. He further distinguished Ctenotaenia Railliet, 1893 (previously considered synonymous with Cittotaenia) and Mosgovoyia, in which the earlystage uterus has the form of a transverse tube. Mosgovoyia was accepted by Yamaguti (1959), but neither of these genera was recognized by Joyeux and Baer (1961, p. 550) in their synopsis of the systematics of the Cestoda.

Cestodes included in the genus Mosgovoyia are large, ribbonlike forms, occurring typically in leporids. Compared with that of Mosgovoyia, the uterus of Ectopocephalium is situated more anteriorly in the segment, and its ends extend laterad beyond the longitudinal excretory canals. The testes in Ectopocephalium are distributed across the entire segment, passing both dorsally and ventrally beyond the female genital organs, while in Mosgovoyia they are dorsal in position and are posterior to the female genital organs.

\section{Attachment to host tissues}

Numbers of cestodes in each of the six pikas ranged from 2 to 14 , with an average of 7 . In all, the cestodes occupied the sacculus rotundus, attaching anteriorly in the organ just distal to its junction with the ileum; in one specimen of $\mathrm{O}$. roylei, two strobilae had attached additionally in the distal portion of the ileum. The cestodes did not localize at random within the sacculus, but formed one or more lateral aggregations as was apparent also externally from the arrangement of the papillalike structures enclosing the scolices (Fig. 7). The openings through the intestinal wall were usually directed obliquely anteriad, with the external papillae having their long axes nearly parallel with that of the intestine. The free portions of the strobilae were confined within the lumen of the sacculus rotundus.

The sacculus rotundus, a structure peculiar to lagomorphs, is a more or less globular dilatation at the distal end of the ileum. Although similar to the ileum microscopically, it is distinguished by masses of lymphatic tissue un- 


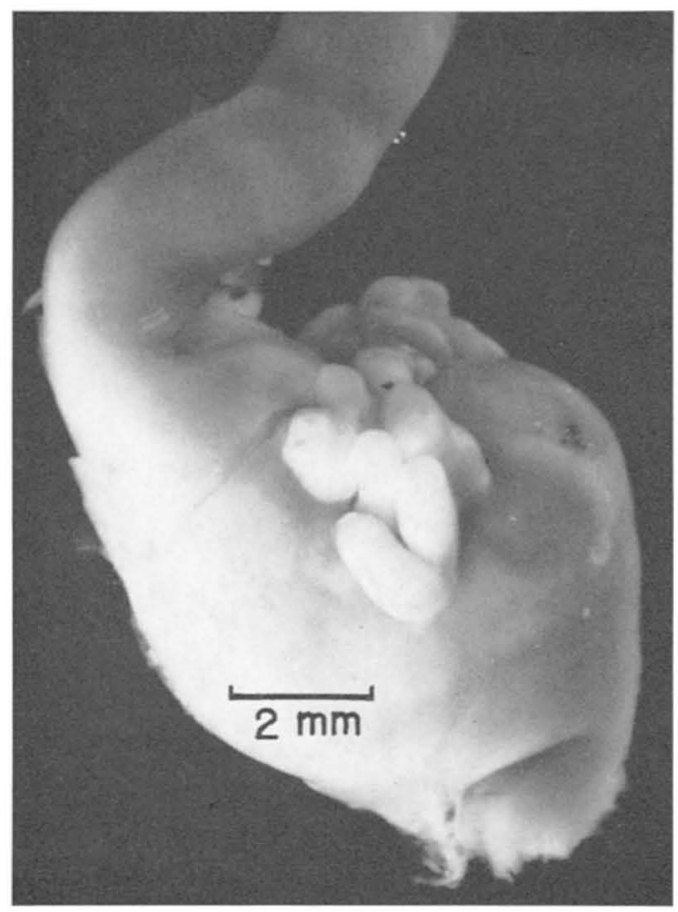

Figure 7. Sacculus rotundus of Ochotona roylei, showing external papillae, each containing the scolex and anterior strobila of $E$. abei.

derlying the mucosa. According to Yamasaki (1968) and Arvy (1972), the various species of Ochotona exhibit morphological differences in the ileocecal region. The sacculus rotundus in Royle's pika is about $10 \mathrm{~mm}$ long by $8 \mathrm{~mm}$ in greatest diameter, with well-developed villi and abundant intestinal glands. The walls, including the mucosa, ranged from about 0.93 to $1.08 \mathrm{~mm}$ in thickness, of which the tunica muscularis made up 100 to 170 ; the lymphatic tissue was as much as 770 thick focally. The muscularis mucosae and the submucosa were very thin. In sacculi rotundi with the cestodes preserved in situ, the tunica muscularis was thinner than that of the ileum, although this might have been partly attributable to distention caused by the strobilae. The organ apparently has an important secretory function. In the rabbit, it produces a serous, alkaline fluid that is low in calcium and phosphorus and high in bicarbonates (Arvy, 1972).

The process by which $E$. abei penetrates the intestinal wall was not entirely clear from the material studied. The youngest cestodes obtained already had well-developed strobilae

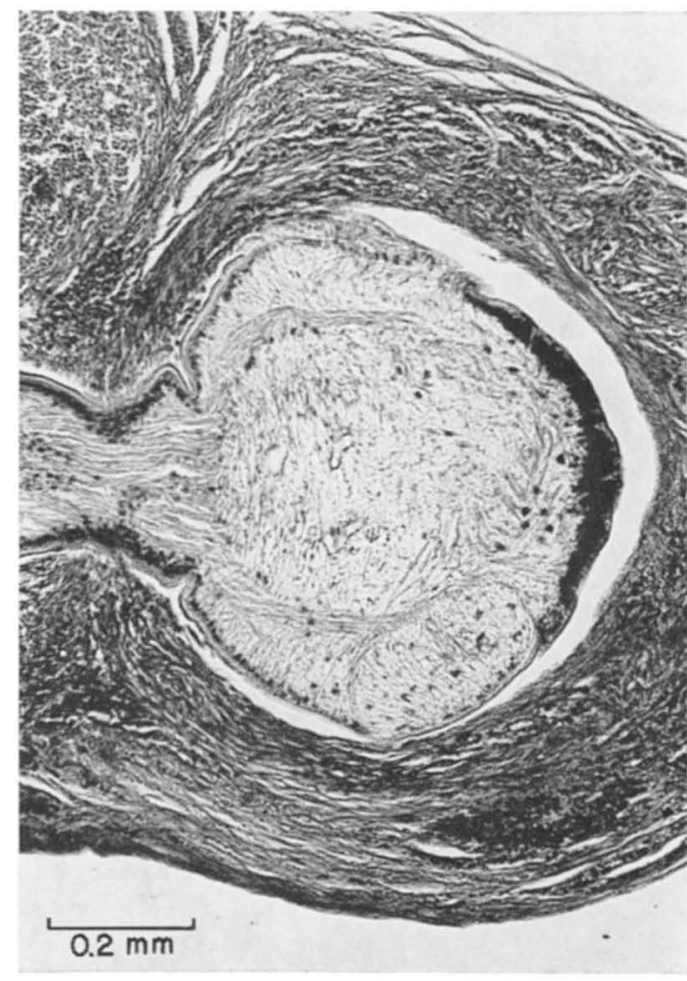

Figure 8. Sagittal section of papilla on sacculus rotundus, with scolex of $E$. abei in situ. Apical glandular cells are black. May-Grünwald stain, gray filter.

with the anterior portions fully embedded. The presence of apical glands in the specialized scolex suggests that penetration of the intestinal wall is mediated by proteolytic enzymes (Fig. 8), but findings in sections indicated that a process other than direct penetration of the successive tissue layers was involved. Serial sections of cestodes in situ revealed in all cases that the mucosa extended through the channel in the intestinal wall into the proximal part of the lumen of the papillae, and isolated islets of mucosa were found farther distally, in the walls of the papillae. The observed relationships of the tissues could be explained on the basis that E. abei initially causes formation of a diverticulum that is later perforated at the apex, with subsequent modification and narrowing of the resulting channel by the inflammatory response. In the one animal that had cestodes attached in the lower ileum, the mucosa similarly extended into the channel through the intestinal wall. 
Among cestodes of higher vertebrates, relatively few attach by embedding the entire scolex in the intestinal wall. Two such species, both collected in Alaska, were compared with E. abei: Priapocephalus minor Nybelin, 1928 (Tetrabothriidae), from a gray whale, Eschrichtius gibbosus Erxleben, and a dilepidid (Dilepidinae) representing an undescribed genus from a common snipe, Capella gallinago (Linnaeus). Sections of the scolices of these cestodes in situ showed that they penetrated the intestinal wall directly, passing successively through the respective tissue layers.

The scolex of $P$. minor is globular, at least $2 \mathrm{~mm}$ in transverse diameter when fully developed, and lacks suckers and rostellum. The apical surface of the scolex is pitted, and provided with abundant glandular cells. The scolex of this cestode penetrated into the submucosa, but did not enter the thick tunica muscularis. Growth of the scolex detached the muscularis mucosae and overlying tissues, producing a small mound in the mucosa, from the center of which the neck of the cestode emerged into the intestinal lumen. The scolex was closely surrounded by a thin layer of connective tissue, but the walls of the cavity were formed mainly by the muscularis mucosae, and the floor by the submucosa. Although the tissue layers were displaced somewhat inward, their relationships had not been altered.

The dilepidid penetrated the full thickness of the intestinal wall, producing an external, subserosal vesicle that enclosed the scolex, an organ with well-developed suckers and a vestigial, unarmed rostellum. The scolex of this cestode penetrated the intestinal wall vertically, passing through each layer in turn. The resulting channel containing the anterior portion of the strobila was lined by a thin layer of connective tissue and other products of the tissue reaction, but the relationships of the intestinal tissues were not modified.

The comparative findings support the interpretation that penetration of the intestinal wall by $E$. abei involves a distinctive process that might best be elucidated by the study of early-stage infections.

\section{Tissue response to $E$. abei}

Of that portion of the strobila within the tissue of the host, the greater part lay ex-

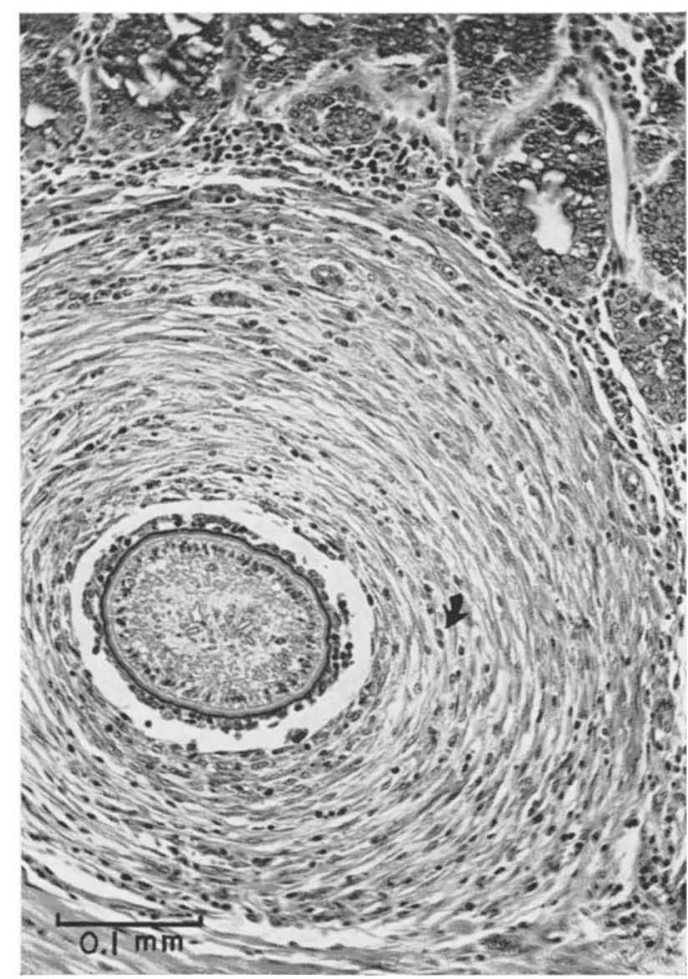

Figure 9. Transverse section of papilla on sacculus rotundus with strobila of $E$. $a b e i$, showing concentric arrangement of fibrous wall. Eosinophils are prominent (arrow). Hematoxylin-eosin, green filter.

ternal to the intestine in a papillalike protrusion, with the scolex at the apex (Fig. 7). In medial sagittal sections, the walls of the papillae ranged in thickness from 186 to 689 near the base, and from 31 to 248 at the apex, adjacent to the scolex (cf. Fig. 8). The walls of the papillae consisted mainly of connective tissue, of which the inner portions were fibrous and the outer part often granulomatous. The tissue was most vascular apically. Externally, the epithelium covering the papillae was usually intact, but reactive changes had sometimes occurred focally on the surface.

Within the sacculus rotundus, the lamina propria contained scattered eosinophils, often with focal aggregations near the openings of the channels containing the strobilae. Eosinophils were present also in the lamina propria of the ileum in which the cestodes had attached, but their numbers decreased anteriad from the lesions. The mucosa characteristically 
lining the channels through the intestinal wall usually showed atrophic changes as a result of contact with the strobilae. The thickness of the mucosa progressively decreased within the papillae, sometimes dwindling to a single layer of columnar cells before disappearing. Eosinophils and histiocytes were usually abundant laterally along the margins of the mucosal extensions into the papillae, as well as around the isolated islets of mucosa farther distad. Degenerating islets of mucosa were occasionally involved in granulomatous reactions.

The tunica muscularis, especially the external layer consisting of longitudinal fibers, also extended into the walls of the papillae proximally. The fibrous tissue immediately surrounding the strobilae was arranged concentrically (Fig. 9). Small numbers of histiocytes and eosinophils were often present in the small space between the strobilae and adjacent walls of the channels. Peripherally, the walls of the papillae exhibited granulomatous formations as much as $1.2 \mathrm{~mm}$ long, in which histiocytes and eosinophils were abundant. In such areas, aggregations of degenerating eosinophils were a common feature. In one of the sectioned papillae, the medial walls of the lumen were involved by an extensive abscess that entirely surrounded the strobila. None of the papillae sectioned or dissected under low magnification contained other than living strobilae.

\section{DISCUSSION}

The family Ochotonidae, represented by the single Recent genus Ochotona, can be traced to the early Oligocene (Thenius, 1972, p. 201). Consistent with the relatively early phyletic distinction of the family, the helminth fauna of pikas includes a considerable number of host-specific genera and shows little affinity with that of the Leporidae (cf. Gvozdev et al., 1970). Cestodes of three genera appear to be restricted in occurrence to pikas: Schizorchis Hanson, 1948; Diuterotaenia Gvozdev, 1961; and Ectopocephalium. Of these, only Schizorchis is known to be polytypic and holarctic in occurrence.

Although ochotonids became widely distributed during the Miocene, Ochotona stems from a precursor that appeared in Asia during the early Pliocene (Thenius, 1972). The North
American species of Ochotona appear to be of relatively recent (late Pleistocene) derivation from a Eurasian precursor. Pikas probably had an extensive geographic distribution in western North America during the last (Eem or Sangamon) interglaciation, after which disruption of their range by the last (Würm) glaciation left residual populations in the Beringian region and south of the continental ice sheet. These populations diverged, as indicated by chromosomal differences (Rausch and Ritter, 1973), and it was considered earlier (Rausch, 1960) that corresponding divergence in Schizorchis accounted for the occurrence of S. ochotonae in the southern $O$. princeps and $S$. caballeroi in the northern $O$. collaris. However, the identification by one of us (RLR) of S. caballeroi in a specimen of $O$. princeps collected in Linn County, Oregon, invalidates this hypothesis.

\section{ACKNOWLEDGMENTS}

This study was based on materials made available by Dr. H. Abe, Institute of Applied Zoology, Faculty of Agriculture, University of Hokkaido, Sapporo. Helminths from Eurasian pikas were provided by Prof. E. V. Gvozdev, Laboratory of Helminthology, Institute of Zoology, Academy of Sciences of the Kazakh SSR, Alma-Ata, and the pikas from Oregon were collected by Mr. C. Maser, Puget Sound Museum of Natural History, University of Puget Sound, Tacoma. At the Arctic Health Research Center, Mrs. V. R. Rausch prepared the figures; Mr. G. C. Kelley provided photographic assistance; Mr. C. Ankrom prepared the tissue sections; and Dr. J. W. Lindsay reviewed some of the microscopic findings. We are grateful for these contributions.

\section{LITERATURE CITED}

ABE, H. 1971. Small mammals of central Nepal. J. Fac. Agric. Hokkaido Univ. 56 (Pt. 4): $367-426$.

ARvy, L. 1972. L'appendice vermiforme ou caecal. Mammalia 36 (Suppl.), 68 p.

Bienek, G. K., and A. W. Grundmann. 1973. A new tapeworm, Schizorchodes dipodomi gen. et sp. n. (Cestoda: Anoplocephalidae), from the Merriam kangaroo rat, Dipodomys merriami vulcani. Proc. Helminthol. Soc. Wash. 40: 192-195. 
Ellerman, J. R., and T. C. S. Morrison-Scott. 1951. Checklist of Palaearctic and Indian mammals 1758 to 1946. Br. Mus. (Nat. Hist. ), London.

Gvozdev, E. V. 1951. Novyi vid tsestod sem. Anoplocephalidae ot pishchukhi. Tr. Gel'mintol. Lab. 5 : 143-145.

. 1962. Analiz gel'mintofauny pishchukh (Ochotonidae) v sviazi c geograficheskim rasprostraneniem khoziaev. Tr. Inst. Zool. Akad. Nauk Kaz. SSR 16: 63-80.

, V. L. Kontrimavichus, K. M. Ryzhikov, AND L. S. Shaldirin. 1970. Opredelitel' gel'mintov zaitseobraznykh SSSR. Nauka, Moskva.

Joyeux, Ch., AND J.-G. BAer. 1961. Classe des Cestodes. Cestoidea Rudolphi. P. 347-560 in Traité de Zoologie. Tome IV. P.-P. Grassé, Ed. Masson, Paris.

Lovekar, C. D., D. Seth, and P. G. Deshmukh. 1972. Schizorchis esarsi n. sp. (Cestoda: Anoplocephalidae) from albino mouse, Mus musculus. Riv. Parassitol. 33: 17-20.

Rausch, R. L. 1960. Studies on the helminth fauna of Alaska. XXXVII. Description of Schizorchis caballeroi n. sp. (Cestoda: Anop- locephalidae), with notes on other parasites of Ochotona. Libro Homenaje al Dr. Eduardo Caballero y C., Mexico, D. F., p. 399-405.

Rausch, V. R., and D. G. Ritter. 1973. Somatic chromosomes of a male collared pika, Ochotona collaris (Nelson) (Lagomorpha: Ochotonidae). Mammal. Chrom. Newsletter 14: 109-111.

SpASsKI, A. A. 1951. Anoplotsefaliaty-lentochnye gel'minty domashnikh i dikikh zhivotnykh. Osnovy tsestod., Vol. 1, Akad. Nauk SSSR, Moskva.

— - AND K. M. Ryzhikov. 1951. Gel'minty pishchukh Pribaikal'ia. Tr. Gel'mintol. Lab. 5: $34-41$.

Thenrus, E. 1972. Grundzüge der Verbreitungsgeschichte der Säugetiere. Eine historische Tiergeographie. Gustav Fischer Verlag, Jena. YamaguTI, S. 1959. Systema Helminthum. Vol. 2. Cestodes of Vertebrates. Interscience Press, New York.

YAMASAKI, F. 1968. Development of the peculiar lymphoid apparatuses on the caecum seen in the region of the ileocaecal junction of the Ochotona. Okajimas Folia Anat. Jap. 44: 285-299. 